\title{
Epstein-Barr virus infection mediated TP53 and Bcl-2 expression in nasopharyngeal carcinoma pathogenesis
}

\author{
CHITTIBABU VATTE ${ }^{1}$, ALI M ALAMRI ${ }^{2}$, CYRIL CYRUS $^{1}$, SHAHANAS CHATHOTH $^{1}$, \\ ARAFAT AHMAD ${ }^{1}$, AHMED ALSAYYAH ${ }^{3}$ and AMEIN AL ALI ${ }^{1}$ \\ ${ }^{1}$ Department of Biochemistry, College of Medicine, Imam Abdulrahman Bin Faisal University, Dammam 31441; \\ Departments of ${ }^{2}$ Internal Medicine and ${ }^{3}$ Pathology, King Fahd Hospital of the University, Imam \\ Abdulrahman Bin Faisal University, Al-Khobar 31952, Kingdom of Saudi Arabia
}

Received June 22, 2021; Accepted September 28, 2021

DOI: $10.3892 / \operatorname{mco} .2021 .2422$

\begin{abstract}
Epstein Barr virus (EBV) stimulates neoplastic transformation of nasopharyngeal epithelial cells through various molecular mechanisms, predominantly affecting inactivation of tumor-suppressor genes and activation of oncogenes. EBV infection is a major risk factor for nasopharyngeal carcinoma (NPC), yet its role in the carcinogenesis is not clear. EBV infection alters the expression of antiapoptotic proteins and tumor suppressor proteins. Therefore, this study investigated the correlation between EBV infection status with B cell lymphoma-2 (Bcl-2) and TP53 protein expression amongst laryngeal and nasopharyngeal cancer cases. This study was performed using 22 nasopharyngeal and 11 laryngeal cancer cases. EBV infection status, TP53 and Bcl-2 protein expression was studied using immunohistochemistry. The majority of the laryngeal cancer cases exhibited a poor prognosis and presented low Bcl-2 expression. A total of $22.7 \%$ cases were infected with EBV in the NPC cases. Upregulated TP53 expression was associated with EBV infection in the NPC cohort, and EBV infection was correlated with TP53 upregulation in the patients with NPC, suggesting mutual regulation between TP53 and EBV.
\end{abstract}

\section{Introduction}

Head and neck squamous cell carcinomas (HNSCCs) comprise a group of cancers that evolve in the mucosal lining of the upper aerodigestive tract. HNSCCs are heterogeneous in nature (1). Nasopharyngeal carcinoma (NPC) and cancer of the larynx are the most prevalent cancers amongst HNSCC,

Correspondence to: Mr. Chittibabu Vatte, Department of Biochemistry, College of Medicine, Imam Abdulrahman Bin Faisal University, P.O. Box No. 1982, King Faial Road, Dammam 31441, Kingdom of Saudi Arabia

E-mail: cbvatte@iau.edu.sa

Key words: Epstein Barr virus, TP53, overexpression, nasopharyngeal cancer, prognosis followed by lip and oral cavity carcinomas (2). As per global cancer statistics, it was reported that 177,422 new laryngeal cancers and 129,079 new NPC cases were diagnosed globally in 2018, and they ranked the 23rd and 25th most commonly occurring cancers, respectively, with an incidence of $1.7 \%$ of all cancers (2).

In 1964, the Epstein-Barr virus (EBV) was the first human tumor virus discovered in Burkitt lymphoma tumor cells (3). Later studies found antibodies in Burkitt lymphoma patients and postnasal space carcinomas (4). De Schryver et al (5) demonstrated EBV antigen detection by immunofluorescence assay, which was followed by zur Hausen et al (6) who used the hybridization method in NPC. EBV infection is very common amongst individuals, and infects $>90 \%$ of populations globally $(7,8)$. Usually, an EBV infection is asymptomatic; however, the involvement of EBV in cancer pathogenesis was established in several epithelial and lymphoid malignancies (9).

The global burden of EBV-associated malignancies increased by $14.6 \%$ between 1990 and 2010, and East Asia accounted for almost $50 \%$ of EBV infected cancer cases during this time period (10). The incidence of EBV-associated cancers is $\sim 1.5 \%$ of all cancers globally and represents $1.8 \%$ of all cancer-associated deaths (11-13). Amongst EBV associated cancer deaths, $92 \%$ are attributable to NPC and gastric cancer (10). The involvement of EBV in the pathogenesis of NPC may be through modification of epigenetic profiles, inducing genomic instability, evading host immunity, promoting cell survival, or contributing stem cell like properties in NPC cells and somatic mutations in apoptotic and tumor suppressor genes (14).

The tumor suppressor p53 and the anti-apoptotic protein B cell lymphoma-2 (Bcl-2) are hypothesized to play a key role in carcinogenesis, and upregulated expression of these proteins has been observed in other types of HNSCC (15). TP53 is a critical tumor suppressor that responds to various stress signals by regulating an anti-proliferative transcriptional program, including transient cell cycle arrest, cellular senescence and apoptosis (16). Despite the wide variety of TP53 network regulators and various TP53 regulated biological pathways, a clear comprehension is lacking about how and in what context TP53 exerts its diverse effects (17). 
Amongst EBV-associated cancers, upregulated expression of wildtype TP53 has been observed, and this was shown to be associated with the latent EBV membrane protein 1 (LMP1). The mutual regulation between TP53 and LMP1 may play a vital role in EBV infection and latency (18). Similarly, Bcl-2, an antiapoptotic protein, is a key inhibitor of programmed cell death or apoptosis in cancer $(19,20)$. In the pathogenesis of $\mathrm{NPC}$, the upregulated expression of Bcl-2 plays an important role by regulating apoptosis (21). The present study evaluated the protein expression pattern of TP53 and Bcl-2 in association with EBV infection in a Saudi cohort with nasopharyngeal and laryngeal cancer to determine the correlation and interplay between these two proteins with EBV infection.

\section{Materials and methods}

Study cohort. Formalin fixed paraffin embedded (FFPE) tissue samples from confirmed nasopharyngeal $(n=22)$ and laryngeal $(n=11)$ carcinoma patients were collected from the Pathology Department, King Fahd Hospital of the University, Imam Abdulrahman Bin Faisal University (IAU), Dammam, Saudi Arabia. The median age of the patients was 51 years (age range, 18-90 years) with 22 males and 11 females forming the cohort. This study was approved by IAU's Institutional Review Board (approval no. IRB-2017-01-059). A signed informed consent form was obtained from each patient included in the study. The procedures in the present study adhered to the principles of the Declaration of Helsinki (22). All the samples were biopsy specimens. Sample size was determined based on the cancer incidence report, Saudi Arabia, 2014 using the 'sample size' module from the Open-Source Project in Epidemiologic Computing program (openepi.com/SampleSize/SSPropor. $\mathrm{htm})$. The tissue samples were collected from the patients who attended the oncology clinic at the King Fahd Hospital of the University between May 2000 and February 2015. Inclusion criteria for the collection of samples was based on the confirmation of a carcinoma of the larynx and/or nasopharynx by histopathology analysis. FFPE samples with $<50 \%$ tumor tissue content were excluded. The present study included only tumor tissue obtained from the patients.

Immunohistochemistry. The FFPE blocks were reassessed for tumor content and diagnosis using Hematoxylin (cat. no. 6765001; Thermo Fisher Scientific, Inc.) and Eosin (cat. no. 6766008; Thermo Fisher Scientific, Inc.) staining. The tissue sections were prepared at room temperature and the total duration of Hematoxylin and Eosin staining procedure was $45 \mathrm{~min}$. Immunohistochemistry was performed to detect TP53 and $\mathrm{Bcl}-2$ protein expression, and EBV infection on $4-\mu \mathrm{MFFPE}$ sections. The primary antibody for TP53 (cat. no. 760-2542; Ventana Medical Systems, Inc.; Roche Diagnostics) used in this study detected the wild and mutant form of the TP53 protein. The anti-Bcl-2 antibody (cat. no. 790-4604; Ventana Medical Systems, Inc.; Roche Diagnostics) binds to the $\mathrm{N}$ terminal region of human $\mathrm{Bcl}-2$ protein. EBV primary antibodies bind to latent membrane protein (LMP-1) of EBV (cat. no. 760-2640; Cell Marque; Sigma-Aldrich; Merck $\mathrm{KGaA}$ ). All of the above antibodies were used without dilution, as they were obtained in a ready to use form. The incubation temperature was $37^{\circ} \mathrm{C}$ for all three antibodies and the timing of the incubation for TP53, Bcl-2 and EBV was 16, 20 and 26 min, respectively. Ultra-View Universal DAB Detection kit (Ventana Medical Systems, Inc.; Roche Diagnostics) was used to visualize the primary antibodies bound to target antigens with hydrogen peroxide substrate and 3,3'-diaminobenzidine tetrahydrochloride chromogen, which produces a brown colored precipitate (Fig. 1). BenchMark ULTRA staining instrument (Roche Diagnostics) was used for staining, and the results were interpreted qualitatively by two independent pathologists using a light microscope (magnification, $\mathrm{x} 40$; Leica Microsystems, Inc.). A tumor cell was considered TP53 positive if they showed nuclear staining and Bcl-2 positivity was confirmed if neoplastic cells showed cytoplasmic and/or nuclear staining. Positive and negative tissue control was used with every staining procedure (Fig. 2). The origin of the control samples for Bcl-2 and TP53 immunohistochemistry were from the tonsils and colon cancer, respectively. The patients were both male, aged 51 years old (tonsil cancer) and 48 years old (colon cancer). These samples were collected from the patients who attended the oncology clinic at the King Fahd Hospital of the University after obtaining consent. An EBV positive control slide was commercially procured (cat. no. CSE0125P; StatLab).

Statistical analysis. The clinical and histopathological data along with studied protein expression (qualitative) results were analyzed using SPSS version 20 (IBM Corp.). Distribution of proportions across category variables were analyzed using a Fisher's exact test (Table I), and for continuous variables an unpaired Student's t-test was used (Table I). The bivariate relationships between the variables were determined using a Spearman's Rank Correlation test (Tables II and III). $\mathrm{P}<0.05$ was considered to indicate a statistically significant difference.

\section{Results}

Sex distribution analysis revealed that in the nasopharynx and larynx groups, 59 and $81 \%$ of the patients, respectively, were males. The median age of patients with nasopharyngeal carcinoma is 49.5 years compared to 65 years in the larynx group $(\mathrm{P}=0.008)$. In the nasopharynx group, $68.2 \%$ had undifferentiated tumors, poorly differentiated tumors accounted for 22.7 and $9.1 \%$ were moderately differentiated tumors. In the larynx group $27.3 \%$ tumors were well differentiated, $63.6 \%$ tumors were moderately differentiated and $9.1 \%$ were poorly differentiated. The majority of the patients with NPC presented with grade $3(86.4 \%)$ disease, whereas in laryngeal cancer cases, grade 1 and 2 tumors (91\%) were predominant $(\mathrm{P}=0.0004)$. Similarly, $54.5 \%$ of the patients with NPC were at an advanced stage of the disease and in the larynx cancer group, the advanced stage was observed only in $27.3 \%$. With regards to smoking, the percentage was higher in the larynx cancer group of patients $(72.7 \%)$ compared to the patients with NPC (36.4\%).

Prognosis was calculated based on the follow-up of the patient for 5 years. Recurrence or death due to disease was considered a poor prognostic outcome. A poor prognosis was observed in $91 \%$ of the larynx cancer patient group compared to $50 \%$ in the patients with NPC $(\mathrm{P}=0.027)$. EBV infection was completely absent in the larynx carcinoma patients, whereas 

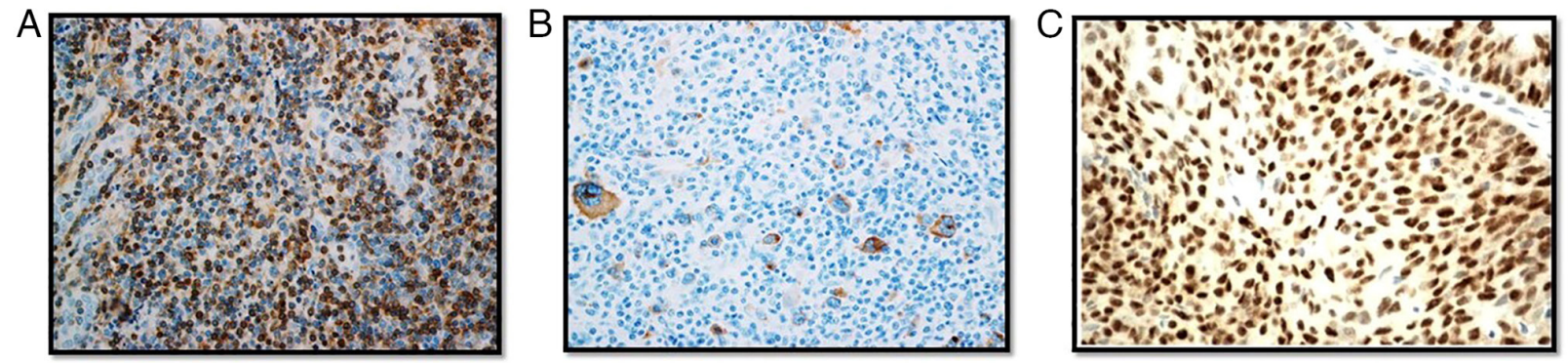

Figure 1. Representative immunohistochemical staining profile images of Bcl-2, EBV and TP53. Representative images of (A) a Bcl-2 positive nasopharyngeal carcinoma sample; (B) EBV positive nasopharyngeal carcinoma sample; and (C) TP53 positive laryngeal carcinoma sample. Magnification, x40. Bcl-2, B cell lymphoma-2; EBV, Epstein Barr virus.
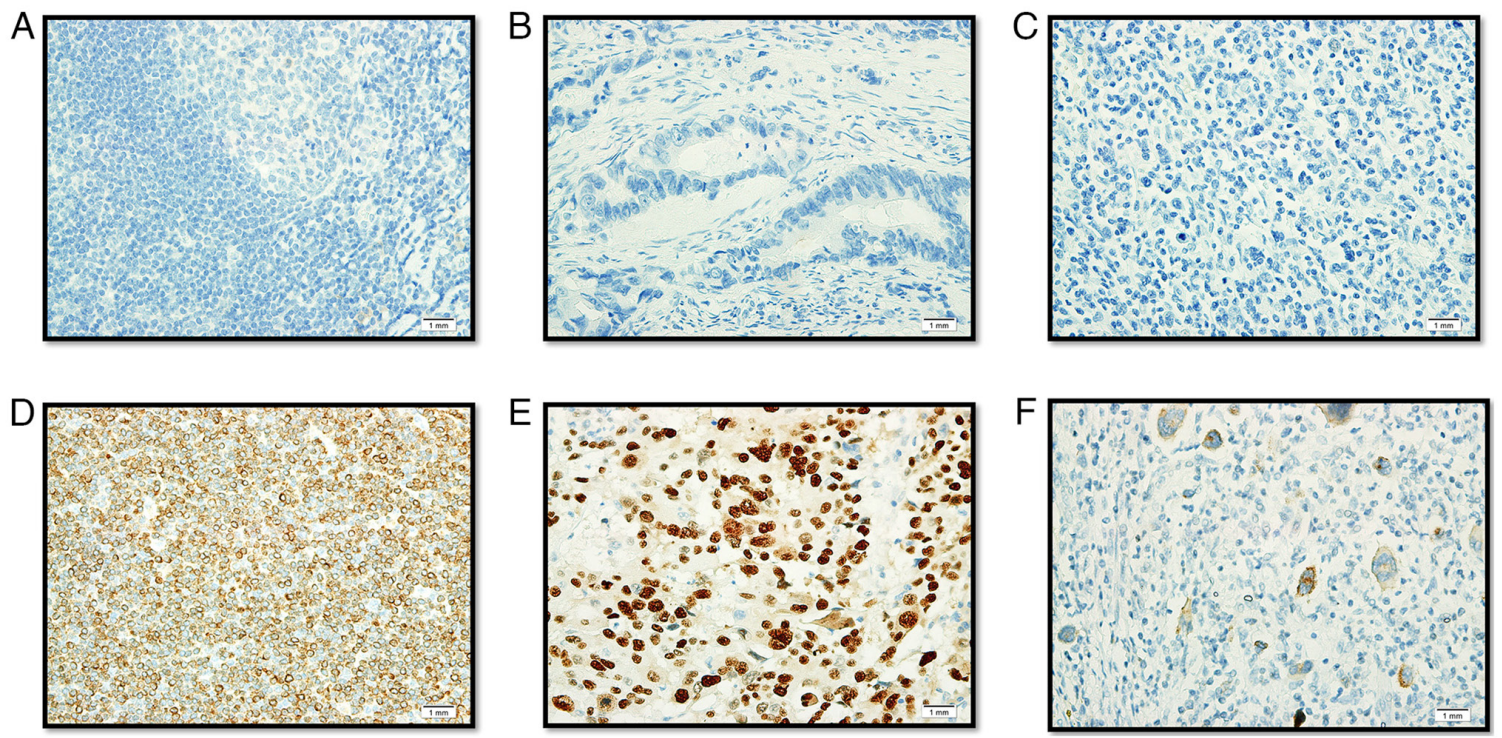

Figure 2. Representative positive and negative immunohistochemical staining profile images of Bcl-2, EBV and TP53. (A) Bcl-2 negative control; (B) TP53 negative control; (C) EBV negative control; (D) Bcl-2 positive control; (E) TP53 positive control; and (F) EBV positive control. Bcl-2, B cell lymphoma-2; EBV, Epstein Barr virus.

$22.7 \%$ of patients were infected with EBV in the NPC group. A high proportion of Bcl-2 expression was seen in the patients with NPC $(\mathrm{P}=0.027)$ compared to the laryngeal carcinoma group. TP53 expression did not yield any significant difference between both patient groups (Table I). Bivariate association between clinical, histopathological and protein expression variables overall, also confirmed the poor prognosis in laryngeal carcinoma patients $(\mathrm{P}=0.002)$ and advanced tumor grade in NPC cases $(\mathrm{P} \leq 0.005$; Table II). These results showed that EBV infection was associated with TP53 expression in the NPC cohort ( $\mathrm{P}=0.009$; Table III).

\section{Discussion}

EBV is currently a well-established carcinogen and an etiological factor implicated in several cancers, including cancer of epithelial and lymphoid origins, gastric cancer, NPC, and Hodgkin's and non-Hodgkin's lymphoma (10). There was a $14.6 \%$ increase in EBV associated cancers between 1990-2010, and $50 \%$ of these cases were observed in patients in East Asia (10). Approximately $1.5 \%$ of cancer cases are associated with EBV infection amongst all cancer cases globally (11-13).
NPC is primarily associated with EBV, and the EBV infection frequency in NPC is varied based on ethnic and geographical differences (23). Almost all the NPC cases from the endemic regions presented with EBV infection and in non-endemic regions, NPC was negative for EBV. The EBV associated NPC prevalence is highest in Southeast Asia (24); data on the frequency of EBV in NPC is scarce in the Saudi population. The present study revealed that $22.7 \%$ of NPC cases had EBV infection. Similarly, the frequency of EBV in NPC was found to be $28 \%$ in an Iranian cohort (8), $44 \%$ from a Brazilian study (25) and 53.84\% in a study from Oman (26). The relatively lower percentage of the EBV infection-associated NPC in the present study may be due to the region of study being non-endemic for EBV (27).

Identifying a single biomarker to calculate the risk and prognosis of a cancer is difficult due to tumor heterogeneity, and distinct clinical and histopathological conditions. However, a single biomarker interaction with other biomarkers in pathways such as cell signaling, apoptosis and cell differentiation may reveal the mechanism of oncogenesis. Hence, Bcl-2 and TP53 protein expression was assessed in all the cases to determine the correlation between EBV infections. The Bcl-2 family 
Table I. Clinical, pathological and protein expression parameters amongst the nasopharynx and larynx group of patients.

\begin{tabular}{|c|c|c|c|}
\hline Parameter & Nasopharynx & Larynx & P-value \\
\hline Sample size & 22 & 11 & \\
\hline Age, years, mean \pm standard deviation & $48.8 \pm 15.4$ & $63.3 \pm 16.2$ & $0.008^{\mathrm{b}}$ \\
\hline Sex, $n$ & & & 0.258 \\
\hline Male & 13 & 9 & \\
\hline Female & 9 & 2 & \\
\hline Grade, $\mathrm{n}$ & & & $0.0004^{\mathrm{b}}$ \\
\hline 1 & 0 & 3 & \\
\hline 2 & 3 & 7 & \\
\hline 3 & 19 & 1 & \\
\hline Stage, $\mathrm{n}$ & & & 0.265 \\
\hline I and II & 10 & 8 & \\
\hline III and IV & 12 & 3 & \\
\hline Smoking status, $\mathrm{n}$ & & & 0.07 \\
\hline Smokers & 8 & 8 & \\
\hline Non-smokers & 14 & 3 & \\
\hline Prognosis, $n$ & & & $0.027^{\mathrm{a}}$ \\
\hline Good & 11 & 1 & \\
\hline $\mathrm{Bad}$ & 11 & 10 & \\
\hline Epstein Barr virus, $n$ & & & 0.143 \\
\hline Positive & 5 & 0 & \\
\hline Negative & 17 & 11 & \\
\hline B cell lymphoma-2, $n$ & & & $0.027^{\mathrm{a}}$ \\
\hline Positive & 11 & 1 & \\
\hline Negative & 11 & 10 & \\
\hline TP53, n & & & 0.712 \\
\hline Positive & 11 & 7 & \\
\hline Negative & 11 & 4 & \\
\hline Chemotherapy, n & & & 0.067 \\
\hline Yes & 7 & 0 & \\
\hline No & 15 & 11 & \\
\hline
\end{tabular}

${ }^{\mathrm{a}} \mathrm{P}<0.05,{ }^{\mathrm{b}} \mathrm{P}<0.01$.

of proteins are key regulators in the apoptotic pathway (19). Amongst Bcl-2 family proteins, there were pro and anti-apoptotic regulators; the Bcl-2 protein is an anti-apoptotic member. $\mathrm{Bcl}-2$ protein upregulation was observed more frequently in NPC cases compared to other types of HNSCC (28), and a similar pattern was observed in the present study; there was a lower frequency of upregulated Bcl-2 expression in patients with larynx cancer compared with patients with NPC. Bcl-2 upregulation was seen in $74.3 \%$ of NPC cases (29), similarly the present study showed that Bcl-2 upregulation was observed in $50 \%$ of NPC tumors. Bcl-2 upregulation may contribute towards tumor cell survival by inhibiting apoptosis in NPC. Thus, Bcl-2 upregulation may highlight a vital mechanism involved in NPC pathogenesis, although the exact molecular mechanism is unclear (30).

TP53 plays a vital role in cell cycle arrest and apoptosis through different mechanisms (31). The positive rate of
TP53 expression in NPC tumors was varied in different studies, with reported values of $34.7 \%$ (32), 65.6\% (33) and $52.2 \%$ (34). The results of the present study are in line with these previous studies with $50 \%$ of the NPC tumors exhibiting TP53 upregulation. The present data revealed that TP53 upregulation is associated with EBV infection in NPC. Similarly, several studies reported wildtype TP53 is upregulated in EBV associated cancers (18,35-37). Apoptosis is induced by TP53 upregulation. However, EBV transformed cells are sensitive to TP53-mediated apoptosis (38). This shows that the EBV positive and EBV negative tumors are distinct groups. The present study detected EBV infection by immunohistochemistry targeting the $60 \mathrm{kDa}$ LMP-1 of EBV, and the results suggested that the mutual regulation between TP53 and LMP1 may play an important role in EBV associated NPC. Additional mechanistic studies need to be performed to determine TP53-mediated LMP1 stimulation. The limitation 
Table II. Correlation between EBV, Bcl-2 or TP53 expression with clinical and histopathological parameters in the total cohort (nasopharynx and larynx groups).

\begin{tabular}{lcccccccc}
\hline & $\begin{array}{c}\text { Smoking status, } \\
\text { r-value }\end{array}$ & $\begin{array}{c}\text { Tumor site, } \\
\text { r-value }\end{array}$ & $\begin{array}{c}\text { Tumor grade, } \\
\text { r-value }\end{array}$ & $\begin{array}{c}\text { Tumor stage, } \\
\text { r-value }\end{array}$ & $\begin{array}{c}\text { Prognosis, } \\
\text { r-value }\end{array}$ & $\begin{array}{c}\text { EBV, } \\
\text { r-value }\end{array}$ & $\begin{array}{c}\text { Bcl-2, } \\
\text { r-value }\end{array}$ & $\begin{array}{c}\text { TP53, } \\
\text { r-value }\end{array}$ \\
\hline Smoking status & 1.000 & -0.320 & 0.156 & -0.97 & 0.099 & 0.078 & -0.170 & 0.182 \\
Tumor site & -0.032 & 1.000 & $-0.614^{\mathrm{a}}$ & -0.291 & $0.480^{\mathrm{a}}$ & -0.178 & -0.213 & 0.190 \\
Tumor grade & 0.156 & $-0.614^{\mathrm{a}}$ & 1.000 & $0.386^{\mathrm{a}}$ & -0.281 & 0.244 & 0.263 & -0.117 \\
Tumor stage & -0.097 & -0.291 & $0.386^{\mathrm{a}}$ & 1.000 & -0.110 & 0.298 & 0.097 & -0.054 \\
Prognosis & 0.099 & $0.480^{\mathrm{a}}$ & -0.281 & -0.110 & 1.000 & -0.031 & -0.056 & 0.210 \\
EBV & 0.078 & -0.178 & 0.244 & 0.298 & -0.031 & 1.000 & -0.036 & $0.361^{\mathrm{a}}$ \\
Bcl-2 & -0.170 & -0.213 & 0.263 & 0.097 & -0.056 & -0.036 & 1.000 & -0.065 \\
TP53 & 0.182 & 0.190 & -0.117 & -0.054 & 0.210 & $0.361^{\mathrm{a}}$ & -0.065 & 1.000 \\
\hline
\end{tabular}

${ }^{\mathrm{a}} \mathrm{P} \leq 0.05$. EBV, Epstein Barr virus; Bcl-2, B cell lymphoma-2.

Table III. Correlation between EBV, Bcl-2 or TP53 expression with clinical and histopathological parameters in the Nasopharynx cohort.

\begin{tabular}{lccccrrr}
\hline Parameter & $\begin{array}{c}\text { Smoking status, } \\
\text { r-value }\end{array}$ & $\begin{array}{c}\text { Tumor grade, } \\
\text { r-value }\end{array}$ & $\begin{array}{c}\text { Tumor stage, } \\
\text { r-value }\end{array}$ & $\begin{array}{c}\text { Prognosis } \\
\text { r-value }\end{array}$ & $\begin{array}{c}\text { EBV } \\
\text { r-value }\end{array}$ & $\begin{array}{c}\text { Bcl-2, } \\
\text { r-value }\end{array}$ & $\begin{array}{c}\text { TP53, } \\
\text { r-value }\end{array}$ \\
\hline Smoking status & 1.000 & -0.025 & -0.394 & 0.378 & 0.184 & -0.378 & 0.378 \\
Tumor grade & -0.025 & 1.000 & -0.099 & 0.132 & 0.215 & 0.132 & 0.132 \\
Tumor stage & -0.394 & -0.099 & 1.000 & 0.076 & 0.262 & -0.038 & -0.356 \\
Prognosis & 0.378 & 0.132 & 0.076 & 1.000 & 0.108 & 0.091 & 0.091 \\
EBV & 0.184 & 0.215 & 0.262 & 0.108 & 1.000 & -0.325 & $0.542^{\mathrm{a}}$ \\
Bcl-2 & -0.378 & 0.132 & -0.038 & 0.091 & -0.325 & 1.000 & -0.091 \\
TP53 & 0.378 & 0.132 & -0.356 & 0.091 & $0.542^{\mathrm{a}}$ & -0.091 & 1.000 \\
\hline
\end{tabular}

${ }^{\mathrm{a}} \mathrm{P} \leq 0.05$. EBV, Epstein Barr virus; Bcl-2, B cell lymphoma-2.

of this study is the absence of quantitative data for the immunohistochemistry experiments.

HNSCCs exhibit a variable prognosis with varying responses to standard treatment modalities, and this may be due to the significant etiological and molecular heterogeneity (39). The present data indicates that laryngeal carcinomas have a poor prognosis compared to NPC. The majority of the patients with NPC tumors presented with a higher grade tumor with a good prognosis. It has been reported that a combination of adjuvant chemotherapy and radiotherapy treatment improves prognosis and survival (40). To the best of our knowledge, this is the first pilot study to reveal the EBV associated NPC frequency using immunohistochemistry in the ethnic population. This study also attempted to divulge the poorly understood cellular mechanisms of EBV associated NPC pathogenesis by determining the correlation between EBV infection and the major tumor suppressor, TP53. Additional mechanistic studies are required to determine the TP53-mediated LMP1 stimulation of EBV in NPC. An improved understanding of the EBV carcinogenic process may aid in the development of novel therapeutics in NPC.

In conclusion, EBV infection was correlated with TP53 upregulation in patients with NPC, which suggests mutual regulation between TP53 and EBV.

\section{Acknowledgements}

The authors would like to thank Mr. Shakir Ahmed (Department of Pathology, King Fahd Hospital of the University, Imam Abdulrahman Bin Faisal University, Kingdom of Saudi Arabia) for his technical support.

\section{Funding}

This work was supported by the Deanship of Scientific Research, Imam Abdulrahman Bin Faisal University (grant nos. 2016-090-IRMC and 2016-111-Med).

\section{Availability of data and materials}

The datasets used and/or analyzed during the present study are available from the corresponding author on reasonable request.

\section{Authors' contributions}

$\mathrm{CV}, \mathrm{CC}, \mathrm{SC}$ and AAA conceived and designed the current study. AMA, AAL and AAH collected samples and the clinical data. $\mathrm{CV}$ and AAS performed the experiments. $\mathrm{CV}$ 
wrote the manuscript. AAA revised the manuscript. All authors read and approved the final manuscript. CV, CC, AMA, AAL, AAA confirm the authenticity of all the raw data.

\section{Ethics approval and consent to participate}

This study was approved by the Institutional Review Board of Imam Abdulrahman Bin Faisal University, Dammam, Saudi Arabia (approval no. IRB-2017-01-059). The procedures in the present study adhere to the principles of the Declaration of Helsinki. Written informed consent was obtained from all patients.

\section{Patient consent for publication}

Not applicable.

\section{Competing interests}

The authors declare that they have no competing interests.

\section{References}

1. Leemans CR, Snijders PJF and Brakenhoff RH: The molecular landscape of head and neck cancer. Nat Rev Cancer 18: 269-282, 2018.

2. Bray F, Ferlay J, Soerjomataram I, Siegel RL, Torre LA and Jemal A: Global cancer statistics 2018: GLOBOCAN estimates of incidence and mortality worldwide for 36 cancers in 185 countries. CA Cancer J Clin 68: 394-424, 2018.

3. Epstein MA and Barr YM: Cultivation in vitro of human lymphoblasts from burkitt's malignant lymphoma. Lancet 1 : 252-253, 1964.

4. Old LJ, Boyse EA, Oettgen HF, Harven ED, Geering G, Williamson B and Clifford P: Precipitating antibody in human serum to an antigen present in cultured burkitt's lymphoma cells. Proc Natl Acad Sci USA 56: 1699-1704, 1966.

5. de Schryver A, Friberg S Jr, Klein G, Henle W, Henle G, De-Thé G, Clifford P and Ho HC: Epstein-Barr virus-associated antibody patterns in carcinoma of the post-nasal space. Clin Exp Immunol 5: 443-459, 1969.

6. zur Hausen H, Schulte-Holthausen H, Klein G, Henle W, Henle G, Clifford P and Santesson L: EBV DNA in biopsies of Burkitt tumours and anaplastic carcinomas of the nasopharynx. Nature 228: 1056-1058, 1970.

7. Cao Y: EBV based cancer prevention and therapy in nasopharyngeal carcinoma. NPJ Precis Oncol 1: 10, 2017.

8. Shahani T, Makvandi M, Samarbafzadeh A, Teimoori A, Ranjbar N, saki N, Nikakhlagh S, Neisi N, Hosseini Z, Pourrezaei S, et al: Frequency of Epstein Barr virus type 1 among nasopharyngeal carcinomas in Iranian patients. Asian Pac J Cancer Prev 18: 327-331, 2017.

9. Young LS and Dawson CW: Epstein-Barr virus and nasopharyngeal carcinoma. Chin J Cancer 33: 581-590, 2014.

10. Khan G and Hashim MJ: Global burden of deaths from Epstein-Barr virus attributable malignancies 1990-2010. Infect Agent Cancer 9: 38, 2014.

11. Varmus $\mathrm{H}$ and Kumar HS: Addressing the growing international challenge of cancer: A multinational perspective. Sci Transl Med 5: $175 \mathrm{~cm} 2,2013$.

12. Holmes D: The cancer-virus cures. Nat Med 20: 571-574, 2014.

13. Lieberman PM: Virology. Epstein-Barr virus turns 50. Science 343: 1323-1325, 2014.

14. Tsao SW, Tsang CM and Lo KW: Epstein-Barr virus infection and nasopharyngeal carcinoma. Philos Trans R Soc Lond B Biol Sci 372: 20160270, 2017.

15. Sahoo R, Chittibabu V, Patil G, Rao S, Thakur S, Dhondalay G, Kulkarni AJ, Banerjee A, Ajaikumar BS, Korlimarla A, et al: Relationship between molecular markers and treatment response in a retrospective cohort of Indian patients with primary carcinoma of the larynx. Oral Oncol 45: e216-e221, 2009.
16. Bieging KT, Mello SS and Attardi LD: Unravelling mechanisms of p53-mediated tumour suppression. Nat Rev Cancer 14: 359-370, 2014.

17. Kastenhuber ER and Lowe SW: Putting p53 in Context. Cell 170: 1062-1078, 2017.

18. Wang Q, Lingel A, Geiser V, Kwapnoski Z and Zhang L: Tumor suppressor p53 stimulates the expression of epstein-barr virus latent membrane protein 1. J Virol 91: e00312-17, 2017.

19. Chipuk JE, Moldoveanu T, Llambi F, Parsons MJ and Green DR: The BCL-2 family reunion. Mol Cell 37: 299-310, 2010.

20. Kelly PN and Strasser A: The role of Bcl-2 and its pro-survival relatives in tumourigenesis and cancer therapy. Cell Death Differ 18: 1414-1424, 2011.

21. Wenmei S, Yanming L, Fenping W, Hongsheng G, Lixia L, Suwen Z, Zhennan L, Rong L and Zhixiong Y: Bcl-2 regulation by miR-429 in human nasopharyngeal carcinoma in vivo. Int J Clin Exp Pathol 9: 5998-6006, 2016.

22. World Medical Association: World medical association declaration of Helsinki: Ethical principles for medical research involving human subjects. JAMA 310: 2191-2194, 2013.

23. Kanno M, Narita N, Fujimoto Y, Wakisaka N, Yoshizaki T, Kodaira T, Makita C, Sato Y, Yamazaki K, Wakaoka T, et al: Third epidemiological analysis of nasopharyngeal carcinoma in the central region of Japan from 2006 to 2015. Cancers (Basel) 11: 1180, 2019.

24. Ngan HL, Wang L, Lo KW and Lui VWY: Genomic landscapes of EBV-associated nasopharyngeal carcinoma vs. HPV-associated head and neck cancer. Cancers (Basel) 10: 210,2018

25. Breda E, Catarino RJ, Azevedo I, Lobão M, Monteiro E and Medeiros R: Epstein-Barr virus detection in nasopharyngeal carcinoma: Implications in a low-risk area. Braz J Otorhinolaryngol 76: 310-315, 2010.

26. Al-Shidhani SNS, Al-Sinawi S, Al-Bahri M, Al-Kindi M and Mabruk M: Determination of the expression of latent Epstein Barr virus in Omani nasopharyngeal carcinoma patients. Biomed Pharmacol J 14: 257-265, 2021.

27. Wu L, Li C and Pan L: Nasopharyngeal carcinoma: A review of current updates. Exp Ther Med 15: 3687-3692, 2018.

28. Yang HJ, Cho YJ, Kim HS, Chang MS, Sung MW and Kim WH: Association of p53 and BCL-2 expression with Epstein-Barr virus infection in the cancers of head and neck. Head Neck 23: 629-636, 2001

29. Sarac S, Akyol MU, Kanbur B, Poyraz A, Akyol G, Yilmaz T and Sungur A: Bcl-2 and LMP1 expression in nasopharyngeal carcinomas. Am J Otolaryngol 22: 377-382, 2001.

30. Tulalamba W and Janvilisri T: Nasopharyngeal carcinoma signaling pathway: An update on molecular biomarkers. Int J Cell Biol 2012: 594681, 2012.

31. Muller PA and Vousden KH: p53 mutations in cancer. Nat Cell Biol 15: 2-8, 2013.

32. Tabyaoui I, Serhier Z, Sahraoui S, Sayd S, Cadi R, Bennani OM, Benider A, Zamiati S and Tahiri JN: Immunohistochemical expression of latent membrane protein 1 (LMP1) and p53 in nasopharyngeal carcinoma: Moroccan experience. Afr Health Sci 13: 710-717, 2013.

33. Zhang P, Wu SK, Wang Y, Fan ZX, Li CR, Feng M, Xu P, Wang WD and Lang JY: p53, MDM2, eIF4E and EGFR expression in nasopharyngeal carcinoma and their correlation with clinicopathological characteristics and prognosis: A retrospective study. Oncol Lett 9: 113-118, 2015.

34. Liu J, Liu Y, Zhang Z, Sun H, Ji X, Li B, Zhou X and Gai P: Prognostic value of the Epstein-Barr virus and tumor suppressor gene p53 gene in nasopharyngeal squamous cell carcinoma. J Cancer Res Ther 15: 426-436, 2019.

35. Menke DM, Griesser H, Moder KG, Tefferi A, Luthra HS, Cohen MD, Colon-Otero G and Lloyd RV: Lymphomas in patients with connective tissue disease. Comparison of p53 protein expression and latent EBV infection in patients immunosuppressed and not immunosuppressed with methotrexate. Am J Clin Pathol 113: 212-218, 2000.

36. Niemhom S, Kitazawa S, Murao S, Kunachak S and Maeda S: Co-expression of $\mathrm{p} 53$ and bcl-2 may correlate to the presence of epstein-barr virus genome and the expression of proliferating cell nuclear antigen in nasopharyngeal carcinoma. Cancer Lett 160: 199-208, 2000.

37. Chou J, Lin YC, Kim J, You L, Xu Z, He B and Jablons DM: Nasopharyngeal carcinoma-review of the molecular mechanisms of tumorigenesis. Head Neck 30: 946-963, 2008. 
38. Allday MJ, Sinclair A, Parker G, Crawford DH and Farrell PJ: Epstein-Barr virus efficiently immortalizes human B cells without neutralizing the function of p53. EMBO J 14: 1382-1391, 1995.

39. Belcher R, Hayes K, Fedewa S and Chen AY: Current treatment of head and neck squamous cell cancer. J Surg Oncol 110: 551-574, 2014.
40. Perri F, Della Vittoria Scarpati G, Buonerba C, Di Lorenzo G, Longo F, Muto P, Schiavone C, Sandomenico F and Caponigro F: Combined chemo-radiotherapy in locally advanced nasopharyngeal carcinomas. World J Clin Oncol 4: 47-51, 2013.

cc) (i) $\ominus$ This work is licensed under a Creative Commons EY NO NO Attribution-NonCommercial-NoDerivatives 4.0 International (CC BY-NC-ND 4.0) License. 